
кафедра спеціалізованих комп'ютерних систем

\title{
МЕТОД ПРОСТОРОВОЇ ІДЕНТИФІКАЦЇ̈ ДЖЕРЕЛА АКУСТИЧНИХ СИГНАЛІВ У ДВОВИМІРНОМУ ХЕММІНГОВОМУ ПРОСТОРІ
}

\author{
(C) Трембач Б. Р., 2017
}

Викладено теоретичні основи кореляційного методу просторової ідентифікації джерела акустичних сигналів у двовимірному хеммінговому просторі декартових координат.

Запропоновано структурну модель полігона просторової ідентифікації джерел акустичних сигналів у декартових координатах двовимірного хеммінгового простору 3 пріоритетним розміщенням мікрофонів як приймачів акустичних сигналів. Наведено приклади аналітичних розрахунків системних характеристик апаратної та часової складності кореляційної системи на основі визначеної кількості мікрофонів та відповідної кількості взасмокореляторів. Розроблено структурні рішення апаратної спецпроцесорної реалізації такого класу багатоканальних пристроїв розпізнавання та ідентифікації типів і просторового розміщення джерел акустичних сигналів. Показано можливість застосування такого класу пристроїв у галузі спецтехніки воснного призначення.

Ключові слова: акустичні сигнали, корелятори, спецпроцесори, хеммінговий простір.

B. Trembach

Lviv Polytechnic National University, Specialized Computer Systems Department

\section{METHOD OF SPATIAL IDENTIFICATION OF ACOUSTIC SIGNALS SOURCE IN THE TWO-DIMENSIONAL HEMMING SPACE}

(C) Trembach B., 2017

The theoretical bases of the correlation method of spatial identification of the source of acoustic signals in the two-dimensional Hemming space of Cartesian coordinates are described.

The structural model of the spatial identification of sources of acoustic signals in Cartesian coordinates of a two-dimensional Hemming space with the priority placement of microphones as receivers of acoustic signals is proposed. Examples of analytical calculations of the system characteristics of the hardware and time complexity of the correlation system based on a certain number of microphones and the corresponding number of interrelations are presented. The structural solutions of the hardware special processor implementation of such a class of multichannel devices for recognition and identification of types and the spatial location of sources of acoustic signals are developed. It is shown the possibility of using such a class of devices in the field of special military equipment of military use.

Key words: acoustic signals, correlators, special processors, Hemming space.

Вступ

Розроблення теоретичних засад, методів та програмно-апаратних засобів ідентифікації просторового розміщення джерел акустичних сигналів (ДАС) є актуальним прикладним науковим 
завданням теорії розпізнавання образів на основі кореляційного аналізу часових характеристик акустичних сигналів (АС) у двовимірному хеммінговому просторі. Успішно розв'язати цю задачу можна в одновимірному векторному просторі, а також у двовимірному хеммінговому просторі у декартових та полярних координатах [1-3]. Практичне застосування таких теоретичних положень ефективне для кореляційної ідентифікації у спецтехніці воєнного призначення [4-5].

\section{Теоретичні основи розпізнавання образів у хеммінговому просторі}

Задача ідентифікації просторового розміщення ДАС належить до класу задач теорії розпізнавання образів у хеммінговому просторі.

Інформаційна технологія розпізнавання образів у хеммінговому просторі грунтуються на опрацюванні та перетворенні сигналів, поданих у дискретній формі, до яких належать: алгебраїчний, кореляційний, структурний, спектральний, геометричний, на основі нечітких множин, статистичний, просторово зв'язаних процесів тощо.

Аналітика відомих методів розпізнавання образів формалізується такими функціоналами:

$d_{i j}$ - оцінка евклідової відстані між $i$-м та $j$-м об'єктами;

$\mathrm{x}_{i k}-$ дискретне значення $\kappa$-ї ознаки $i$-го об' єкта;

$\mathrm{x}_{j k}$ - дискретне значення $\kappa$-ї ознаки $j$-го об' єкта;

$v$ - кількість ознак, якими описуються об'єкти.

Згідно $з$ положеннями кластерного аналізу визначено, що оцінкою евклідової відстані між об' єктами у хеммінговому просторі за всією сукупністю ознак, якими описуються класифіковано розпізнавані об'єкти, є деяка величина $d_{i j}$, що визначається згідно з виразом

$$
d_{i j}=\sum_{k=1}^{k}\left|x_{i k}-x_{j k}\right|
$$

і задовольняє такі аксіоми:

1) $\quad d_{i j}>0$ (позитивність хеммінгової відстані);

2) $\quad d_{i j}=d_{j i}$ (симетрія);

3) $\quad d_{i j}+d_{j i}>d_{\kappa}$ (нерівність трикутника);

4) $\quad d_{i j} \neq 0$ то $i \neq j$ (нетотожні об'єкти);

5) $\quad d_{i j}=0$ то $i=j$ (нероздільність тотожних об’єктів).

Крім лінійної оцінки евклідової відстані (1), застосовують квадратичну оцінку виду:

$$
d_{i j}=\sum_{k=1}^{k}\left(x_{i k}-x_{j k}\right)^{2} .
$$

Ця оцінка не дає квадратичного зростання інформаційності та точності розпізнавання границь класів об’єктів, тобто еквівалентна зваженій оцінці евклідової відстані згідно з виразом

$$
d_{i j}=\sum_{k=1}^{k} v_{k}\left|x_{i k}-x_{j k}\right|,
$$

де $v_{k}$ - вагова функція.

Прикладом зваженої оцінки евклідової відстані є ступеневі відстані Мінковського, в яких застосовують деякі числа $\mathrm{p}$

$$
d_{i j}=\left(\sum_{k=1}^{k} v_{k}\left|x_{i k}-x_{j k}\right|^{\frac{1}{p}}\right.
$$

Граничною оцінкою такої евклідової відстані є оцінка “манхеттенської” відстані, коли $p \rightarrow \infty$, що також називається метрикою “домінування”, або Sup-метрикою і розраховується згідно з виразом

$$
d_{i j}=\left(\sum_{k=1}^{k} v_{k}\left|x_{i k}-x_{j k}\right|\right)^{\frac{1}{\alpha}} \text {. }
$$


Принципово відмінною від наведених метрик оцінки евклідової відстані у хеммінговому просторі є метрика Махаланобіса, яка визначається за виразом

$$
d_{i j}=\left(X_{i}-X_{j}\right)^{T} \times S^{-i}\left(X_{i}-X_{j}\right),
$$

де $X_{i}$ та $X_{j}$ - відповідні вектори стовпців змінних ознак $i$-го та $j$-го об'єктів; символ $T$ визначає операцію транспонування вектора, а символ $S$ групову дисперсійно-коваріаційну матрицю.

Отже, коли кореляції між змінними $i$-го та $j$-го об’єктів дорівнюють нулю, відстань Махаланобіса еквівалентна квадрату евклідової відстані.

Викладений аналіз теоретичних основ розпізнавання образів на основі оцінок евклідової відстані у хеммінговому просторі дає підстави констатувати таке:

1) відомі методи вузькоспеціалізовані та проблемно-орієнтовані й не характеризуються універсальністю;

2) найзагальніші оцінки хеммінгової відстані грунтуються на розрахунку коваріаційних та статистичних характеристик ознак $i$-го та $j$-го об'єктів;

3) відомі застосування методів розпізнавання образів у хеммінговому просторі застосовують бінарні значення векторів ознак $i$-го та $j$-го об' єктів типу “0” та “1”, що передбачає застосування кореляційного аналізу на основі знакової взаємокореляційної функції:

$$
H_{i j}=\frac{1}{n} \sum_{i=1}^{n} \operatorname{sign}\left(\stackrel{\circ}{x_{i}}\right) \times \operatorname{sign}\left(\stackrel{\circ}{x_{j}}\right)
$$

де $\operatorname{sign}\left(x_{i}\right)=\left\{\begin{array}{c}\circ \\ +1, \text { якщзо } x_{i} \geq 0 ; \\ \circ \\ -1, \text { якщзо }{ }_{x}<0\end{array} ; \operatorname{sign}\left(x_{j}\right)=\left\{\begin{array}{c}\circ \\ +1, \text { якщзо } x_{j} \geq 0 \\ \circ \\ -1, \text { якщзо } x_{j}<0\end{array}\right.\right.$;

$$
\stackrel{\circ}{x_{i}}=x_{i}-M_{x} ; \stackrel{\circ}{x_{j}}=x_{j}-M_{j} ; M_{i}=\frac{1}{n} \sum_{i=1}^{n} x_{i} ; M_{j}=\frac{1}{n} \sum_{i=1}^{n} x_{j} .
$$

Істотного розширення та підвищення ефективності розпізнавання образів у хеммінговому просторі можна досягти застосуванням різних дискретних оцінок взаємокореляцій, аналітику яких наведено у [6].

\section{Класифікація дискретних хеммінгових просторів}

Існують такі класи дискретних хеммінгових просторів:

1) одновимірний, що задається одновимірним вектором та масивом інформаційних вузлів (рис. 1);

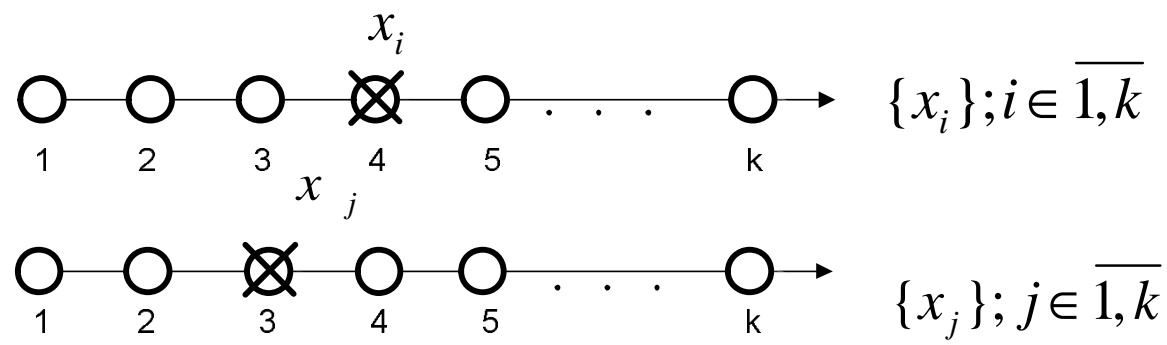

Рис. 1. Масиви інформаџійних вузлів одновимірних векторів

2) двовимірний просторовий, що задається решіткою 3 двовимірними вузлами у декартових координатах (рис. 2); 


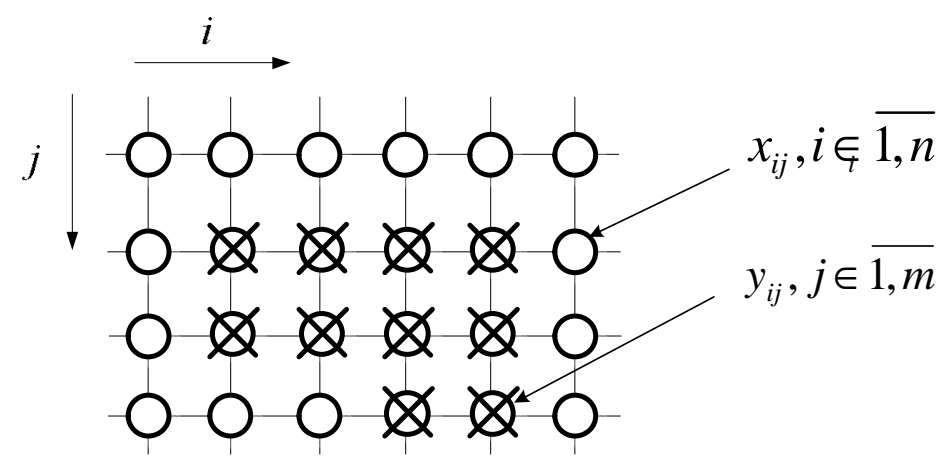

Рис. 2. Інформаційні вузли двовимірного хеммінгового простору

3) двовимірний у полярних координатах, що задається решіткою вузлів у полярних координатах (рис. 3).

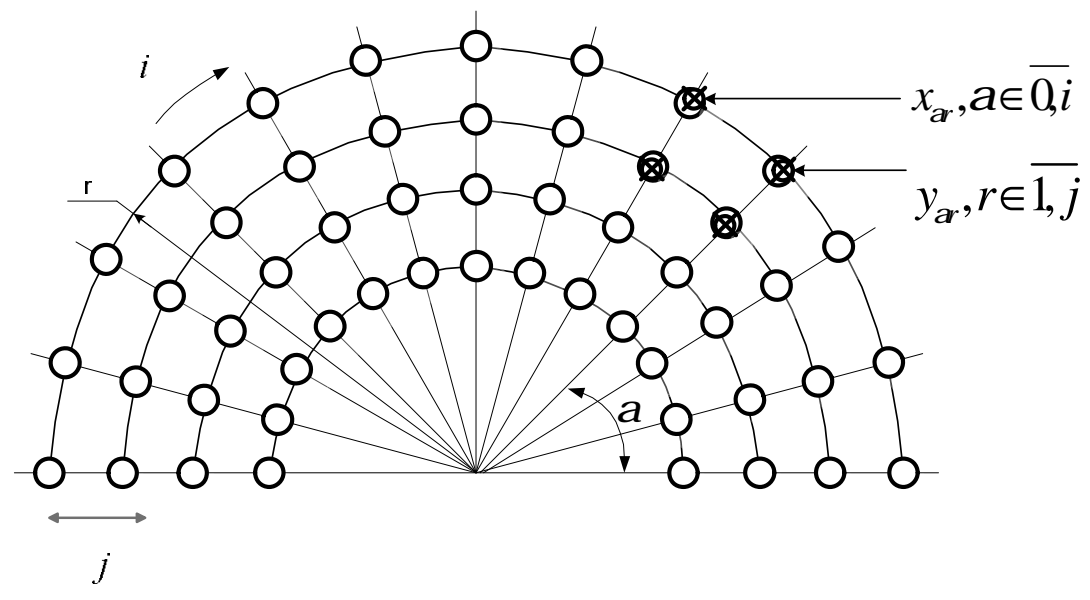

Рис. 3. Двовимірний хеммінговий простір у полярних координатах

\section{Методи ідентифікації віддалі до джерела акустичних сигналів (ДАС) у різних хеммінгових просторах \\ Градіснтний метод}

У роботі [6] запропоновано градієнтний метод ідентифікації віддалі до ДАС у векторному одновимірному хеммінговому просторі (рис. 4) на основі просторової діаграми зміни потужності акустичного сигналу (АС)

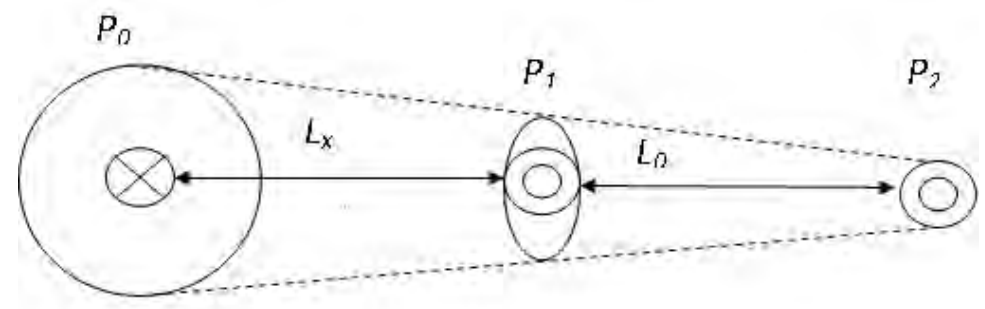

ДAC

Рис. 4. Просторова діаграма зміни потужності ДАС

Математична формалізація цієї задачі така:

$$
P_{L_{x}}=P_{0} \cdot e^{-\alpha L_{x}}, \Delta P=P_{1}-P_{2}=e^{-\alpha L_{x}}-e^{-\alpha L_{0}}=e^{-\alpha\left(L_{x}-L_{0}\right)}
$$




$$
\begin{gathered}
\ln \Delta P=\alpha\left(L_{x}-L_{0}\right) ; L_{x}-L_{0}=\frac{\ln \Delta P}{\alpha} ; \\
L_{x}=L_{0}+\frac{\ln \Delta P}{\alpha},
\end{gathered}
$$

де $\alpha$ - коефіцієнт загасання енергії акустичного сигналу в атмосфері.

Для реалізації спеціалізованого засобу визначення віддалі до ДАС градієнтним методом використовувати функцію натурального логарифма неефективно. Тому доцільніше застосувати функцію двійкового логарифма, поширеного у практиці комп'ютерної техніки. Тобто вираз (4) набуде вигляду

$$
L_{x}=L_{0}+\frac{\log _{2} \Delta P}{k \cdot \alpha} .
$$

При цьому $\log _{2} \Delta P$ дорівнюе двійковому коду $\Delta P$, який формується на виході спецпроцесора згідно зі структурою (рис. 5).

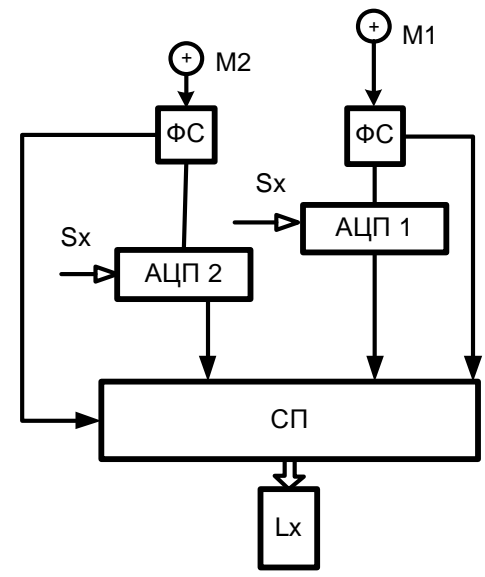

Рис. 5. Структура спейпоцесорного пристрою визначення відстані

до ДАС градієнтним методом: $M_{1}, M_{2}$-мікрофони; ФСформувачі акустичних сигналів, які ідентифікують тип ДАС (наприклад, артилерійську установку); АЦП - аналоговоuฺифрові перетворювачі; СП - спецпроцесор, який реалізує алгоритм (4)

У разі вибору $k \alpha=2^{n}$ операція ділення у алгоритмі (4) також замінюється операцією зсуву на розряди ознаки цілої частини у двійковому коді $L_{x}$. Оскільки $\left.P_{1}\right\rangle P_{2}$, то обчислювальна операція $\Delta P=P_{1}-P_{2}$ реалізується додаванням прямого $P_{1}$ та доповнювального $P_{2}$ вихідних кодів АЦП1 та АЦП2 3 паралельним вихідним двійковим кодом, формувачі акустичних сигналів реалізуються у вигляді цифрових інтегрувальних квадраторів.

У разі застосуванні АЦП послідовного наближення, які формують $k$-розрядні біторієнтовані вихідні коди, у процесі іх формування може виконуватися біторієнтована операція додавання коду $P_{1}$ та інвертованого коду $P_{2}$ в однорозрядному накопичувальному суматорі згідно зі структурою (рис. 6).

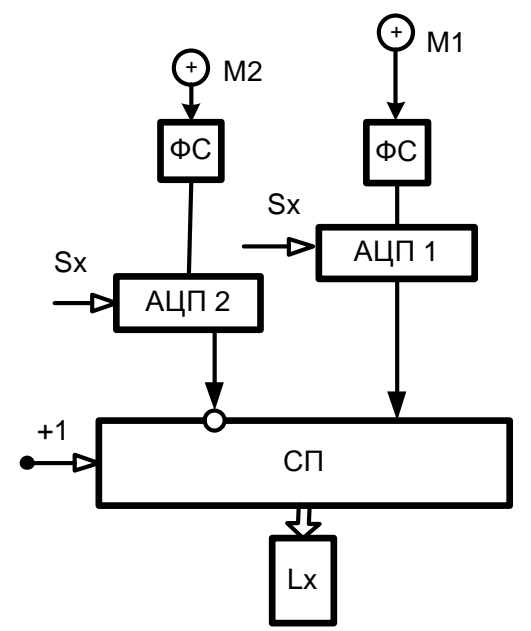

Рис. 6. Структура спецпрочессорного пристрою ідентифікаиії відстані

до ДАС градієнтним методом на основі АЦП послідовного наближення: СП-спецฺпроцеесор 
У цих структурах СП містить два регістри зсуву і багаторозрядний двійковий суматор. У перший регістр зсуву записується прямий вихідний код АЦП $\left(\mathrm{P}_{1}\right)$, а у другий регістр інвертований вихідний код $\left(\bar{P}_{2}\right)$. У результаті додавання цих кодів у багаторозрядному суматорі формується код $L_{x}$.

Реалізація такого СП виконується на базі кристала ПЛІС відповідної фірми виробника. Враховуючи дуже просту мікроелектронну реалізацію такого спеціалізованого пристрою, вони можуть бути тиражовані й одночасно паралельно виконувати просторове сканування ДАС у декартових чи полярних координатах хеммінгового простору.

\section{Двовимірний простір}

У роботі [7] викладено методологію визначення координат ДАС у двовимірному просторі на основі заданого розміщення на певній відомій віддалі між собою (рис. 7).

Рис. 7. Схема просторового розташування акустичної бази АВ звукоприймачів та ДАС $0 ; t_{1}, t_{2}$ - часова тривалість проходження акустичних сигналів відстані $O A$ та $O B$

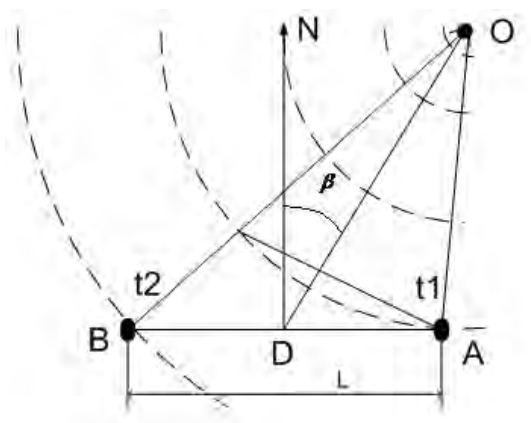

Якщо $\mathrm{AB}<<\mathrm{OB}$, ідентифікація віддалі до ДАС визначається значенням:

$$
\sin \beta=\sin (N D O)=\frac{\left(t_{2}-t_{1}\right) \times C}{L}=\frac{\Delta t \times C}{L},
$$

де $C$ - швидкість поширення звуку в атмосфері.

Спрощення алгоритму обчислення кута напрямленості ( $\beta$ ) згідно 3 виразом (5) можна досягти вибором базової віддалі $L$. Наприклад, $L=16 ; 32 ; 64 ; 256$ м, що дає змогу спростити операцію ділення на $L$, відкинувши $k$ розрядів двійкового коду в добутку $\Delta t \times C$.

Інакше можна спростити алгоритм обчислення (5) заданням $L$, кратним до швидкості поширення звуку в атмосфері $C=330 \mathrm{~m} / \mathrm{c}$. Тобто вибрати $L=k \times c$ серед значень 0,$33 ; 3,3 ; 33 ; 330 \mathrm{~m}$, що дасть змогу вилучити операцію ділення у виразі (5) і виконувати обчислення згідно з виразом

$$
\sin (\beta)=k \times \Delta t,
$$

а якщо $L=330$ м - за виразом $\sin (\beta)=\Delta t$,

Для встановлення координати ДАС необхідно визначити напрямки до нього за певного розміщення мінімум двох акустичних баз, причому той самий звукоприймач може входити до складу декількох акустичних баз.

\section{Кореляційний метод ідентифікації координат ДАС у декартовій системі хеммінгового простору}

Під час приймання акустичного сигналу описаними методами, як показано на рис. 4 та рис. 7 , необхідно формувати параметр його потужності, приклад якого наведено на рис. 8.

У роботі [5] запропоновано практично ідентичний спосіб формування оцінки потужності АС взаємокореляційним перемноженням сигналів, які приймають два акустичні приймачі, згідно 3 виразом:

$$
L(q)=G\left(\int_{\tau(i, q)-\frac{w}{2}}^{\tau(i, q)+\frac{w}{2}} x_{i}(t) \times x_{j}\left(t-\tau_{i, q}+\tau_{j, q}\right) d t\right)+\alpha V_{E},
$$


де $q$ - ідентифікатор ДАС; $G$ - інтегральна функція взаємокореляції; $x_{i}(t)$ та $x_{j}\left(t-\tau_{i, q}\right)-$ відповідно поточні та затримані на інтервалі часу $\pm \tau_{i, q}$ акустичні сигнали; $\alpha V_{E}$-коефіцієнт загасання енергії функції взаємокореляції на інтервалі $\tau_{i, q}$.

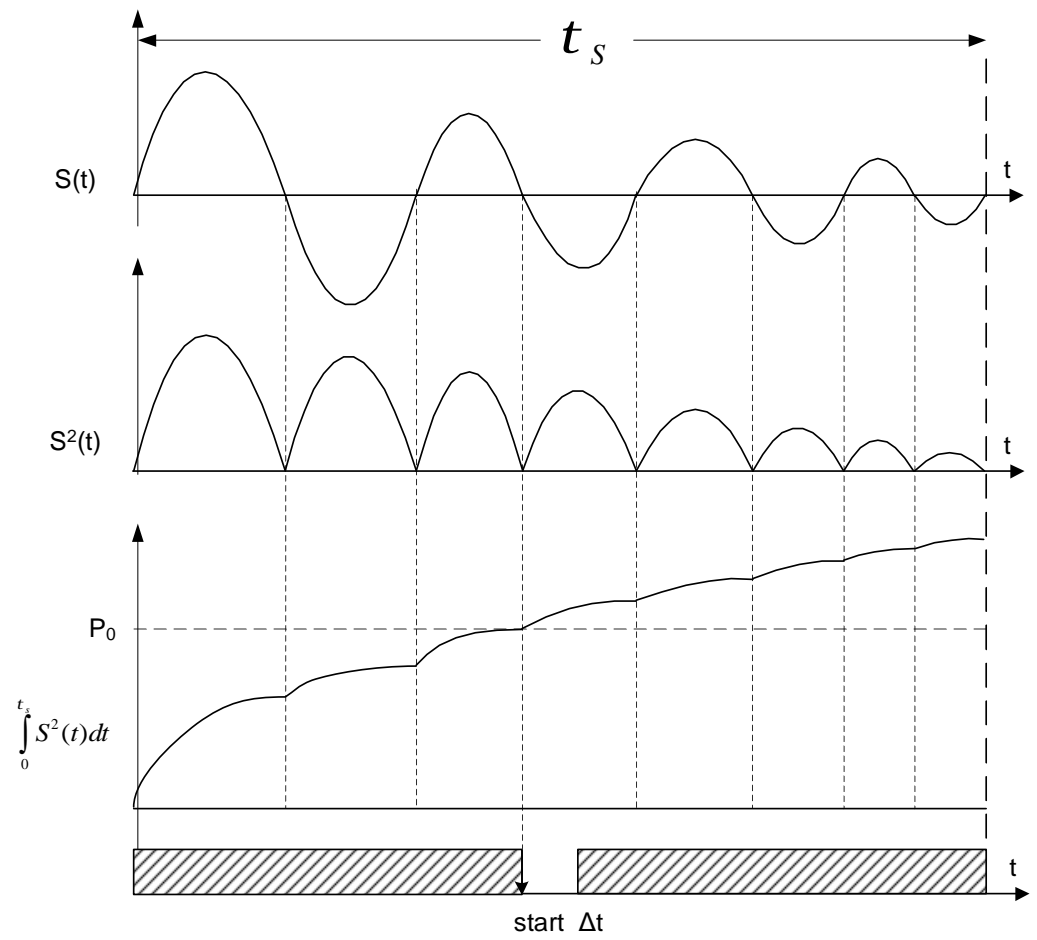

Рис. 8. Часова діаграма формування характеристики потужності AC на часовому інтервалі та стартового значення порогової уставки потужності

У роботах $[8,9]$ показано, що реалізація кореляторів у аналоговому вигляді істотно обмежує можливості реалізації кореляційного опрацювання АС цифровими методами та їх реалізації на базі мікроелектроніки та на кристалах ПЛІС. У цій роботі також запропоновано аналітику цифрової коваріаційної функції згідно з виразом

$$
R_{x x}(j)=\frac{1}{n} \sum_{i=}^{n} \stackrel{\circ}{x \times x_{i-j}^{\circ}} ; \quad j \in \overline{0, m},
$$

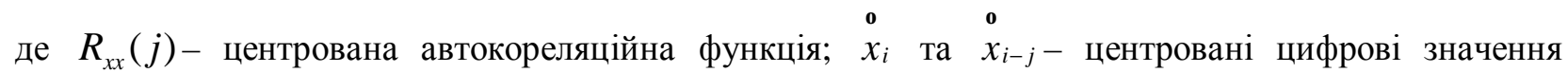
аналогових сигналів $x_{i}(t)$ та $x_{j}(t-\tau) ; n-$ об’єм вибірки масиву даних $\left\{\begin{array}{l}\text { o } \\ x_{i}\end{array}\right\} ; m$ - кількість точок кореляційної функції $R_{x x}(j) ; j$ - дискретна одиниця затримки цифрового відліку $x_{i-j}$ у часі.

Запропоновано базову структуру цифрового спецпроцесора кореляційного опрацювання акустичних сигналів.

Аналіз виразу (7) та відповідно структури цифрового спецпроцесора показує, що наявність операції центрування та перемноження знакозмінних цифрових кодів $\pm \stackrel{\circ}{x_{i}} \times \stackrel{\circ}{ \pm} x_{i-j}$ ускладнює реалізацію такого спецпроцесора та істотно знижує його швидкодію порівняно 3 його функціонально еквівалентною реалізацією на основі оцінки хеммінгової відстані згідно з виразом дискретної оцінки модульної функції кореляції

$$
G_{i j}=\frac{1}{n} \sum_{i=j=1}^{n}\left|x_{i}-x_{j}\right|,
$$

у якому відсутні операції центрування та перемноження. 
Застосування оцінки хеммінгової відстані на основі розрахунку модульної кореляційної функції дає змогу реалізувати операцію визначення модульної різниці між двома цифровими значеннями АC $\left|x_{i}-x_{i-j}\right|$ у мікроелектронному виконанні, запропонованому в [10-12], згідно зі структурою, поданою на рис. 9.

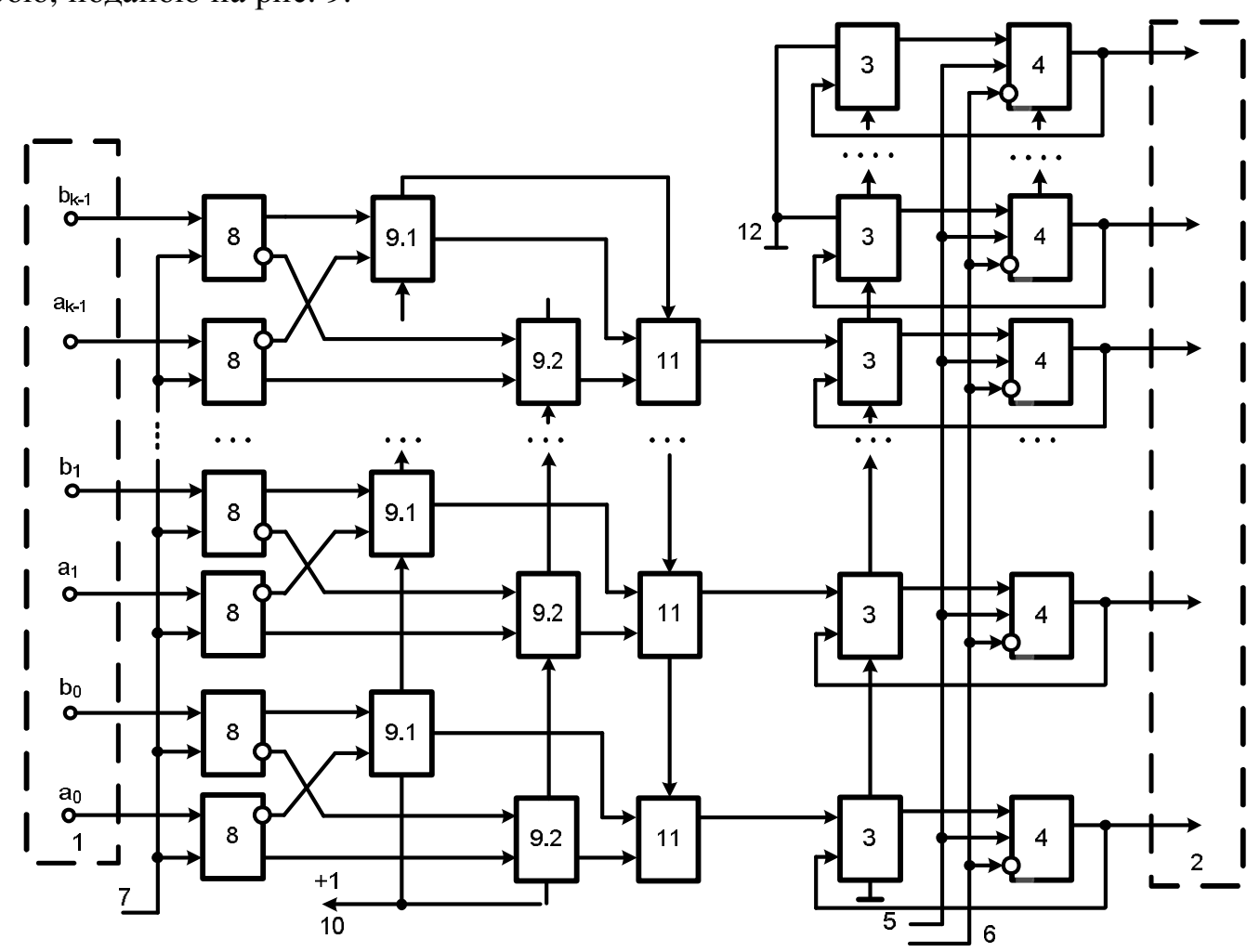

Рис. 9. Структурна схема пристрою додавання багаторозрядних двійкових чисел

На рис. 9 зображена схема пристрою: 1 - вхідна $2 k$-розрядна шина $\left(a_{o}, a_{1}, \ldots, a_{n-1}\right.$ та $b_{o}, b_{1}, \ldots, b_{n-1}-$ відповідні входи $x_{i}$ та $y_{i}$ багаторозрядних двійкових чисел); 2 - вихідна $k+m-$ розрядна шина; $3-k+m-$ розрядний накопичувальний суматор; $4-k+m-$ розрядний паралельний регістр; 5 - перший вхід синхронізації запису; 6 - другий вхід синхронізації скидання у нуль; 7 третій вхід синхронізації запису; $8-D$-тригери $2 k$-розрядного паралельного регістра; 9.1 та $9.2-$ однорозрядні повні суматори відповідно першого та другого $k$-розрядних суматорів; $10-$ вхід логічної одиниці; 11 - розрядні компоненти мультиплексора; 12 - вхід логічного нуля.

Пристрій працює так. На початку роботи пристрою після подавання сигналу синхронізації у вигляді фронту наростання на вхід синхронізації 6 скидання у нуль $k+m$-розрядного паралельного регістра 4 на вихідній $k+m$-розрядній шині 2 формується двійкове число нуль, яке також надходить на перші входи $k+m$-розрядного накопичувального суматора 3.

Після подавання аналогового сигналу на вхід синхронізації 7 вхідні двійкові числа $x_{i}$ та $y_{i}$ записуються у $D$-тригери $2 k$-розрядного паралельного регістра. Вихідні прямі та інверсні коди тригерів подаються на відповідні перші та другі входи першого 9.1 та другого $9.2 k$-розрядних суматорів. У результаті логічними сигналами перенесення у старшому розряді суматора 9.1 , який надходить на керуючий вхід мультиплексора, на його виходах формуються прямі коди модульних різниць між двома двійковими числами $\left|x_{i}-y_{i}\right|$, які подаються на входи $k+m$-розрядного накопичувального суматора 3 , де додаються до коду, який сформований на виходах $k+m$-розрядного паралельного регістра 4, а отримана на виходах суматора 3 сума записується i запам'ятовується у регістрі 4. Після $n$ циклів роботи пристрою отриманий у регістрі 4 код суми модульних різниць двійкових чисел надходить на вихідну $k+m$-розрядну шину у вигляді $k+m$ $n$-розрядного двійкового коду, починаючи зі старших розрядів паралельного регістра 4. 
Наявність додаткового входу логічної одиниці на входах перенесення нульових розрядів суматорів 9.1 та 9.2 дає змогу одночасно з формуванням зворотних кодів двійкових чисел $\bar{x}_{i}$ та $\bar{y}_{i}$ на інверсних виходах $D$-тригерів $2 k$-розрядного паралельного регістра 8 формувати їх доповнювальні коди на входах суматорів 9 без додаткових операцій.

Якщо на виході перенесення старшого розряду суматора 9.1 формується логічна “1” , це означає, що число $x_{i}>y_{i}$ і на виході першого суматора 9.1 формується код модульної різниці $\left|x_{i}-y_{i}\right|$, який $з$ виходу мультиплексора надходить на другі входи накопичувального суматора 3. Якщо на такому виході формується логічний “0”, це означає, що число $x_{i}<y_{i}$, а на виході суматора 9.1 формується результат у вигляді доповнювального коду, який не надходить на вихід мультиплексора 11. На вихід мультиплексора 11 надходить прямий код модульної різниці $\left|x_{i}-y_{i}\right|$, сформований на виході суматора 9.2.

\section{Кореляційний метод ідентифікації просторового розміщення ДАС у декартових координатах хеммінгового простору}

Кореляційний метод ідентифікації віддалі до ДАС, розроблений у роботі С. Бічфілда та Д. Гіллмора [5], оснований на застосуванні чотирьох акустичних приймачів, довільно просторово розміщених на полігоні, та шести аналогових взаємокореляторів, які виконують паралельне опрацювання АС згідно з виразом (2). Недоліки цього структурного рішення кореляційної системи ідентифікації просторового розміщення ДАС такі:

- пристрій не дає змоги опрацьовувати акустичні сигнали у цифровій формі;

- його неможливо реалізувати у вигляді мікропроцесорного спецпроцесора на кристалі або ПЛІС.

Метою вдосконалення такого класу кореляційної системи є:

1) реалізація цифрового представлення та кореляційного опрацювання АC;

2) зменшення кількості мікрофонів та цифрових кореляторів системи;

3) зменшення алгоритмічної та апаратної складності та підвищення швидкодії цифрових кореляторів;

4) реалізація табличного методу ідентифікації просторового розміщення джерел акустичних сигналів на основі часових затримок акустичних сигналів між мікрофонами;

5) адаптація цифрового корелятора до форми акустичних сигналів, які генеруються різними джерелами звуку.

Для досягнення такої мети запропоновано метод кореляційного опрацювання акустичного сигналу з пріоритетним розміщенням мікрофонів [13] на основі мультиплікативної функції (4), зведеної до нормованої форми (8).

Незважаючи на успішне розв'язання задачі визначення часової затримки акустичних сигналів між мікрофонами $\Delta t$, така структура спецпроцесора не дає змоги самостійно визначити просторові координати джерела акустичного сигналу, оскільки потребує більше ніж однієї бази. Тобто об'єм апаратного обладнання такої системи зростає практично у два рази. Крім того, застосування мультиплікативних кореляційних функцій $R_{x x}(j)$ та $\rho_{x x}(j)$ потребує реалізації модулів перемноження та накопичення у реверсивних суматорах знакозмінних цифрових даних, що істотно ускладнює алгоритм опрацювання цифрових даних та апаратну реалізацію такої системи.

3 метою оптимізації характеристик досліджуваної кореляційної системи запропоновано іiі реалізацію на основі трьох мікрофонів, з пріоритетним просторовим розміщенням одного 3 них на полігоні та застосуванням модульної кореляційної функції $G i j$, яка дає змогу ідентифікувати часові затримки між акустичними сигналами $\Delta t_{1}, \Delta t_{2}$ та $\Delta t_{3}$ на основі оцінки евклідової відстані у двовимірному хеммінговому просторі. 
Реалізація такого принципу цифрового опрацювання акустичних сигналів дає змогу істотно зменшити апаратну складність пристрою обчислення модульної кореляційної функції одного двоканального корелятора, структуру якого наведено на рис. 10. Пристрій містить: 1.1, 1.2, 1.3 - відповідно: перший пріоритетний, другий та третій приймачі акустичних сигналів; 2 - пристрої автоматичного регулювання підсилення; 3 узгоджений фільтр акустичних сигналів; 4 вхід еталонного акустичного сигналу; 5 синхронізатор; 6 - АЦП паралельного типу 3 вихідними кодами у двійковій системі числення теоретико-числового базису Радемахера; 7 - багатоканальний регістр зсуву; 8 - логічні елементи I; 9 - пороговий накопичувач модульних різниць; 10 - RSтригери; 11 - двійкові лічильники; 12 модульно-різницевий суматор; 13 координатна система на основі постійного запам'ятовувального пристрою (ПЗП).

На початку циклу роботи пристрою

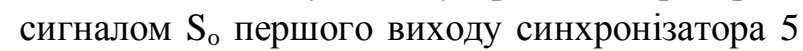
формується стартовий імпульс, який скидає у нульовий стан регістри пам'яті всіх накопичувальних суматорів модульних різниць 9 , входів тригерів 10 та двійкових лічильників 11 .

Вхідні аналогові акустичні сигнали $x(t)$, $y(t), \quad z \quad(t)$, які генеруються віддаленим джерелом акустичних сигналів, надходять на вхід приймача акустичних сигналів 1.1 , який просторово ближче розміщений до джерела

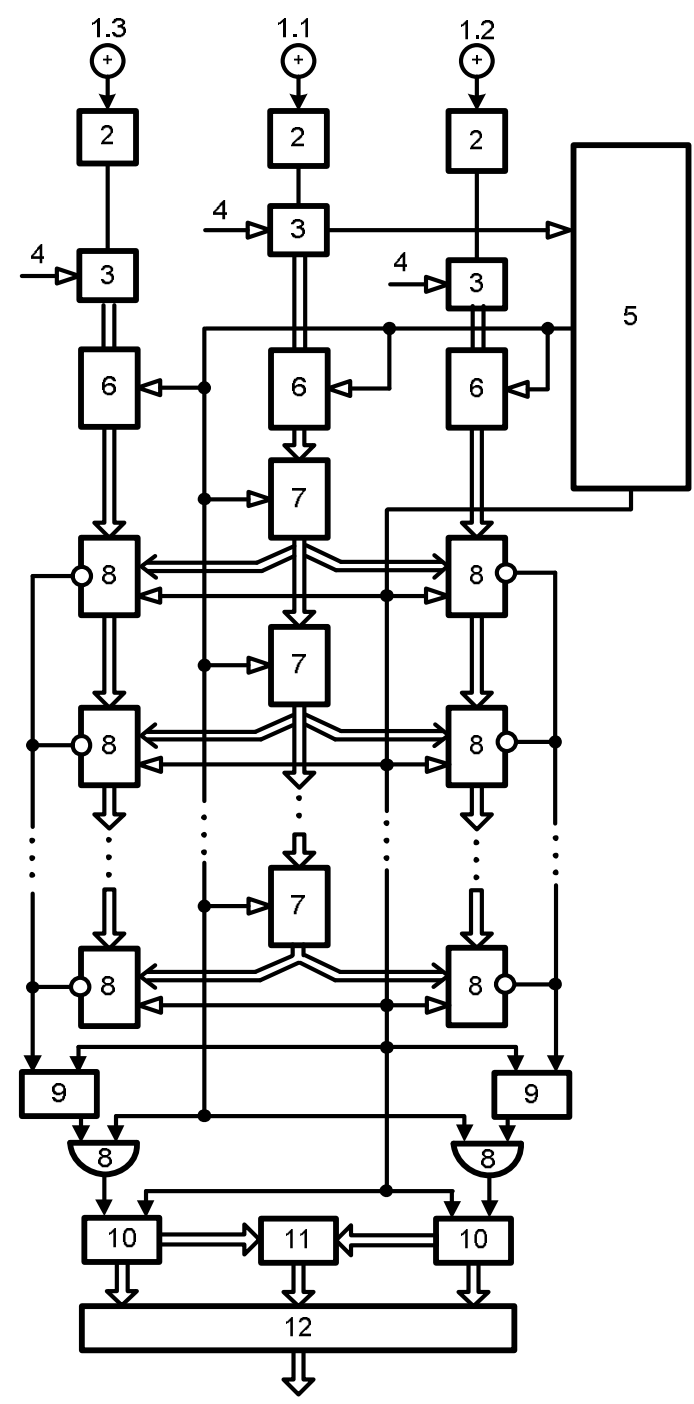

Рис. 10. Структурна схема багатоканального пристрою для обчислення модульної кореляційної функиії

акустичних сигналів та 3 деякою затримкою у часі $\Delta t_{1}$ та $\Delta t_{2}$ відповідно надходять на входи відповідних приймачів акустичних сигналів 1.2 та 1.3. Сформовані на виходах приймачів акустичних сигналів 1.1, 1.2 та 1.3 електричні сигнали надходять на входи відповідних пристроїв автоматичного регулювання підсилення 2, на виході яких формуються електричні сигнали, нормовані за амплітудою та позитивним взірцевим потенціалом. Сформовані у такий спосіб вихідні сигнали пристроїв автоматичного регулювання підсилення 2 надходять на перші входи узгоджувальних фільтрів 3, другі входи яких з'єднані з входами введення еталонних акустичних сигналів 4, а виходи - 3 першими входами відповідних АЦП 6.

Упродовж циклу роботи пристрою тактувальними сигналами другого виходу синхронізатора 5 $\mathrm{S}_{\mathrm{x}}$ здійснюється синхронізація формування вихідних кодів $x_{i} y_{i}$ та $z_{i}$ на виходах відповідних АЦП 6, відповідних зсувів цифрових кодів $x_{i-j}$ у багатоканальному регістрі зсуву 7 та імпульсів, які надходять 3 виходів відповідних логічних елементів $I 8$ на входи відповідних лічильників 10 . При цьому у накопичувальних суматорах модульних різниць 9 першої та другої груп формуються відповідні порогові суми $\sum_{i=1}^{n}\left|x_{i-j}-y_{i}\right| \bmod P ; \sum_{i=1}^{n}\left|x_{i-j}-z_{k}\right| \bmod P$, у разі перевищення яких у одному з каналів кожної групи на інвертованих виходах накопичувальних суматорів модульних різниць 9 формується нульовий потенціал, який перекидає у одиничний стан по S- входу відповідний тригер 10. 
Накопичена сума імпульсів у першому лічильнику $11 \Delta t_{1}$ та у другому лічильнику $11 \Delta t_{2}$ надходять на перший і другий входи координатної системи 13, а отримана модульна різниця у модульно-різницевому суматорі 12 у вигляді коду $\Delta t_{3}$ - на третій вхід координатної системи 13 , вихід якої є виходом пристрою.

На рис. 11 показано часову діаграму формування та опрацювання акустичних сигналів 3 реєстрацією часових затримок між трьома мікрофонами $\Delta t_{1}, \Delta t_{2}$ та $\Delta t_{3}$ і вибраних з ПЗП відповідних значень координат джерела звуку.

Наприклад, якщо $\Delta L=1 \mathrm{~m} ; i \in \overline{1,256}, j \in \overline{1,256}$, що відповідає двійковим кодам $i$ та $j$ розрядністю 8 біт, кількість ідентифікованих джерел звуку з координатами $C i j$ дорівнюватиме $128^{2}=8192$, а при $i \in \overline{1,64}$ та $j \in \overline{1,128}$ відповідно $32 \times 64=2048$, а при $i \in \overline{1,16}$ та $j \in \overline{1,32}$ відповідно $8 \times 16=128$. Тобто це відповідає просторовим габаритам полігонів цілей $256 \times 256 ; 64 \times 128$ та $8 \times 16$ м.

Застосування багатьох автономних систем паралельної пеленгації джерел акустичних сигналів з відповідно невеликим за кількістю вузлів хеммінговим простором дає змогу істотно знизити вимоги до точності цифрового подання значень $\Delta t_{1}, \Delta t_{2}$ та $\Delta t_{3}$.

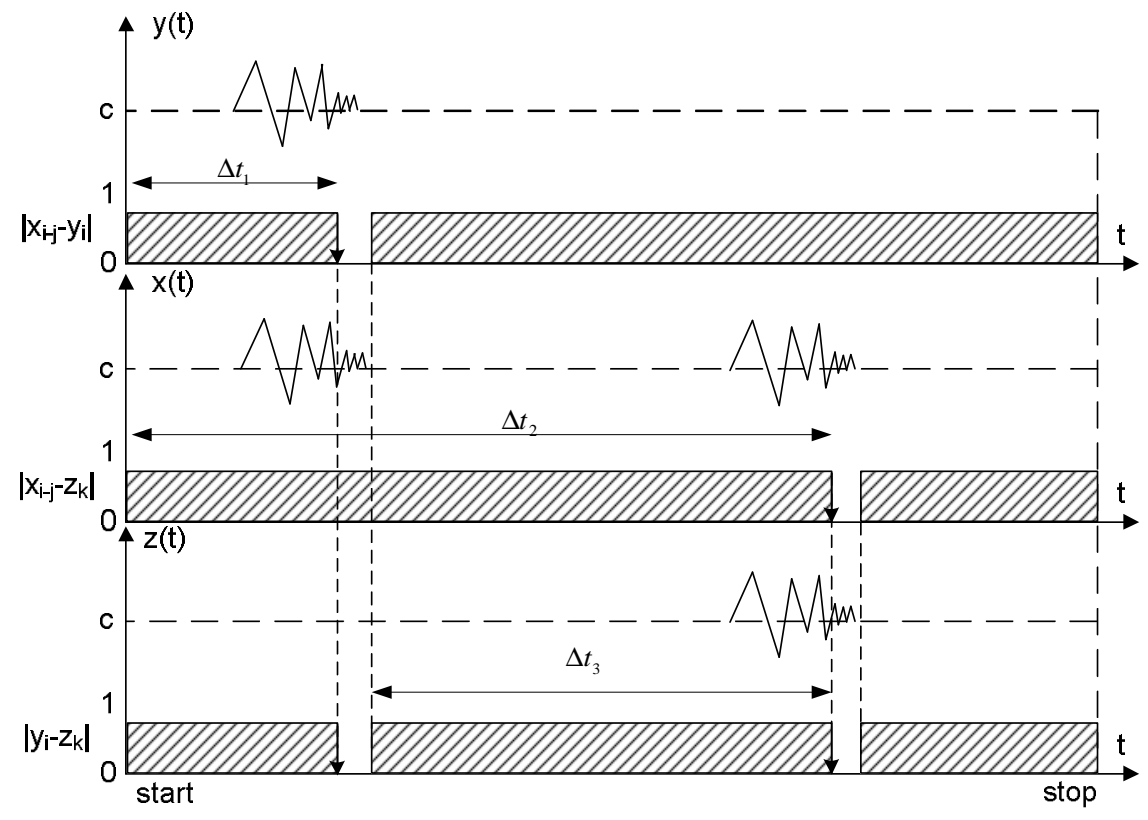

Рис. 11. Часова діаграма кореляиійно-модульного формування кодів часових затримок акустичних сигналів

Необхідний об'єм пам'яті для табличного представлення координат джерела акустичних сигналів, якщо $i \in \overline{1,256}$ та $j \in \overline{1,256}$, становить 256 Кбайт. Тобто відповідну розрядність ПЗП розраховують згідно з виразом

$$
p=n \times m \times \Delta,
$$

де $n$ та $m$ - розрядність двійкового представлення координат ДАС у хеммінговому просторі; а $\Delta-$ пеленгація ДАС в околі чотирьох вузлів.

\section{Висновки}

Виконано аналіз теоретичних засад розпізнавання образів відповідно до різних методів. Обгрунтовано вибір метрики оцінки евклідової відстані у хеммінговому просторі. Систематизовано 
оцінки цифрових кореляційних функцій та обгрунтовано застосування модульної функції кореляції для синтезу схемотехнічної реалізації спецпроцесора визначення цифрових значень часових затримок АС між мікрофонами.

Запропоновано структуру пристрою додавання двійкових чисел, який є базовим компонентом цифрового корелятора і накопичує модульні різниці часових затримок АC.

Подано приклади параметрів оцінювання координат ДАС у двовимірному хеммінговому просторі декартових координат та оцінку об’ємів необхідної пам'яті для табличного розрахунку координат ДАС.

1. Hemming R. V. Theory of coding and theory of information / R. V. Hemming // Trans. eng. - M.: Radio \& communication, 1983. - 176 p. 2. Horbatov A. A. Acoustic methods for measuring distances and control. 2nd ed. redone and add. / Horbatov A. A., H. E. Rudashevski. - M.: Energoizdat, 1981. - 208 p. 3. Talanov A. V. Sound Exploration of Artillery / A. V. Talanov. - M.: Military Publishing House of USSR Armed Forces, 1948. - 404 p. 4. Krivosheev A. M., Petrenko V. N., Prikhodko A. I. Fundamentals of artillery reconnaissance (Textbook)," Sumy: Sumy State University, 2014. - 393 p. 5. Birchfield S. T., Gillmor D. K. Acoustic Localization by Accumulated Correlation. Original: http://www.ces.clemson.edu/ stb/research/acousticloc. 6. Trembach B. Method of determining the distance to the source of acoustic signals / R. B. Trembach // Visnyk of Lviv Polytechnic National University. Computer system and networks. - 2016. - No 857. - P. 102-110. 7. Kochan R., Trembach B. The concept of distributed automated system of sound artillery intelligence-based provider // Modern Information Technologies in the Sphere of Security and Defence, No.1, 2016, pp. 59-63. 8. Trembach Bohdan. Methods of structural design optimization of software hardware problem identification of the spatial parameters of acoustic signals sources / B. Trembach, R. Kochan, R. Trembach // Visnyk of Khmelnitsky national university. - 2017 - No. 1(245). - P. 136-139. 9. Trembach B. Multiplex digital correlator with high priority deployment of one of the acoustic signal receivers / Trembach B., Kochan R., Trembach R. // Scientific Journal of TNTU (Ternopil.). - 2016. - No. 4 (84). - P. 99-104. 10. Trembach B. Patent of Ukraine on the utility model No. 117789, MPK: G06F 7/42(2006.01). Device adding multi-bit binary numbers. / R. Trembach, B. Trembach, A. Sydor. Published: 10.07.2017. Bul. No. 13. 11. Trembach B. Method of identification of the source of acoustic signals in a two-dimensional Hemming space / B. Trembach, A. Sydor, H. Vozna // All-Ukrainian Conference "Modern Computer Information Technologies" ASIT'2017. - 2017. - P. 87-90. 12. Trembach B. The structure and system characteristics of special processors for determination of Heming distance are realized in various theoretical numerical bases / R. Trembach, B. Trembach, A. Sydor, H. Vozna /. Mathematic and computer modeling. Series: Technical sciences. - Vol. 15. - P. 244-250. 13. Bohdan Trembach. The method of correlation study of acoustic signals with priority placement of microphones / Bohdan Trembach, Roman Kochan, Rostyslav Trembach // 14th International Conference The Experience of Designing and Application of CAD Systems in Microelectronics (CADSM), Polyana-Svalyava (Zakarpattya), Ukraine 2017. - P. 210-213. 